\title{
REVIVED SHAMANISM IN THE SOCIAL LIFE OF RUSSIA
}

\author{
Valentina Kharitonova
}

\begin{abstract}
The article reviews various modern practices associated with the concept of revived shamanism. Many of them have an indirect relation to actual shamanism and its revival. However, their adepts can consider themselves followers of traditional shamanism. The author reviews several variants of shamanic activity widely represented in modern Russia, such as: urban shamanism, experiential shamanism, neoshamanism, and also (neo)shamanism or shamanism. They are discussed, taking into account their religious, socio-political, cultural, healing, scientific, ethno-tourist, and economic (business) contexts. The study shows how, depending on various realities of modern life, the activity of specific individuals who identify themselves as shamans, as well as shamanic organisations (legally regarded as religious), changes.
\end{abstract}

Keywords: confession, core shamanism, neoshamanism, religion, revival of shamanism in Russia, shamanism, shamanistic religious organisation, traditional healing, urban shamanism

\section{INTRODUCTION}

When analysing the current state of shamanism in Russia, we have to review quite a wide range of phenomena, which to some extent are included in the complex of what is conventionally referred to as revived shamanism. Many of those phenomena have an indirect relationship particularly to shamanism and its revival. However, their adepts appeal to different traditional variants of shamanism in support of their practices. In this situation the western colleagues would rather use the term 'neoshamanism' - a vague term with many interpretations, allowing researchers and adepts/followers to relate it either to New Age, or to shamanism itself, which has been modernised today (see, e.g., Townsend 2004: 49-56; Winkelman 2004: 187-191).

I see modern versions of shamanic activities (for further details see Kharitonova 2006 and other works by the author) without going beyond the rational interpretation of the phenomenon: the article does not take into account the newspeak creators of shamanic Volkhvy practices, the authors of the new sha- 
manic concepts and texts (see, e.g., Estrin 2006). The materials used are concerned with:

- Urban shamanism (i.e. practices based on indirect knowledge of certain shamanic/ethnic traditions, often the practices of psychologists, combining different variants of healing, including shamanistic; they are widespread mainly in large cities) ${ }^{1}$;

- Experiential shamanism (core shamanism - shamanism by M. Harner, well-rooted in Russia as a result of the work of his disciples, both direct (primarily, A. Slobodova) and indirect (for example, Anzhela Sergeeva). His disciples call this practice basic shamanism);

- Neoshamanism (significantly modernised version of traditional shamanism, which is associated with an indirect reference to the shamanic practices of the successors of traditional shamans);

- (Neo)shamanism or shamanism (reviving the practice of shamans of different traditions directly, through real initiation/training by adepts; yet, these traditions occur with known violations, caused by the modern transformations of the phenomenon as a whole).

The listed variants of shamanic practices have much in common, but they are not entirely similar. And it is clear why: while urban shamanism and experiential shamanism are represented by practices of new 'shamans', who have learned certain techniques (and who, for the most part, are either psychologists or have taken a crash course in psychologies in institutions actively offering the second and third higher education), neoshamanism and (neo)shamanism are represented by those who try to recover their own ethno-cultural traditions, adapting to the contemporary religious and cultural situation in the country, as well as to legislation in the field of health and religious activities.

This is why I refer, if necessary, to different variants of the named shamanisms, reviewing in various contexts the spread and existence of this large-scale phenomenon today. This article engages, quite briefly, some of them: religious, socio-political, cultural, healing, scientific, ethno-tourist, and business contexts. Let us start with the question most important for the renewed practices - about their relations with the religious idea - and consider their religious context. 


\section{HOW SHAMANISM BECAME THE OFFICIAL RELIGION IN THE}

\section{LATE TWENTIETH CENTURY}

The issue of how shamanism is related to religion - originally debatable - gained impetus during the Perestroika period. As it is known, in the early 1990s, three republics - Tuva, Sakha (Yakutia) and Buryatia - included shamanism in the list of traditional religions in their legal documents (for further details see Kharitonova 2006). This action was inscribed in the general context of the 'passions of religion' (stimulated in the country since the 1980s), and national revival. In this context, the term 'shamanism' was used, essentially, for ideological purposes, but it led to a significant transformation of earlier existing practices. Faith is natural for shamans and shamanists; yet, religion with its dogmas and ideological aspirations is excluded from their rich spiritual life: psychology and ideology generate slightly different phenomena. The phenomenon of shamanism, called to life and supported for thousands of years by human psycho-physiology, in the attempts to involve it in ideological programmes of any period of time, turns (a particular part of it) into priestly and religious practices. These practices in fact need for their realisation other professionals who should have somewhat different qualities, characteristics, and abilities than the actual shamans (Kharitonova 2004, 2006; Kharitonova \& Ukraintseva 2007, 2012).

The legalised religious context demanded new ideas from the people who had turned to shamanic practices and joined healing organisations during that period. These ideas appeared in no time in versions borrowed from the wellknown examples of the party and trade union structure (which can also be compared with the administrative system of former kolkhozes); later on they started improving in the direction of copying religious structures. The inclusion of shamanism in the list of official religions necessitated the creation and legal registration of the shamanic organisations that required the availability of some kind of houses of worship, and already existing indoor spaces were easily transformed into them.

Naturally, it did not connect in any way with the traditional shamanic world view and practices of shamanism. However, with time - under the pressure of socio-cultural and religious context - improvement in 'shamanisms' in terms of copying religious ideas and principles gradually became visible. It was not enough anymore to have just a modest shamanic centre / house of worship for the realisation of religious ideas. A plan was devised to build temples or entire temple complexes (e.g. by the Local Religious Organisation of Shamans (LROS) Tengeri in Ulan $\mathrm{Ude}^{2}$, and the Tos Deer and Adyg Eeren in Kyzyl). 
The understanding of their importance and nature of the activities started to transform notably: unusual lexis could be heard in the mouths of shamans: the congregation, prayer, parish, shaman order.

Interestingly, at the same time some of the adepts who considered themselves as (inter alia) shamans, created and revived their 'traditional religions' (the most actively in the regions where Christian Orthodoxy is widespread Yakutia, Khakassia). Here the activity of neoshamans is already moving from a religious to a socio-political context.

\section{SHAMANIC RELIGIOUS ORGANISATIONS AND ELECTIONS OF THE SUPREME SHAMAN}

Certain most active neoshamanic leaders, who had started with the creation of centralised organisations (and without them, as we know, it was impossible, according to the law, to form a confession), later on came up with the idea of uniting the shamans of Siberia, for example. It has not happened yet, but it is quite possible to imagine a union of several national organisations (at least de jure and only on paper). ${ }^{3}$ One of the attempts to centralise was taken by the LROS Tengeri, which organised a regional conference of shamans in April 2011 , but at that time the real unification of all the shamans of Buryatia had not taken place yet. However, the second conference (in April 2013) proved to be more productive, and, as a result, at the end of 2013 the Inter-Regional Centre of Shamans Khaan-Tengeri was established on the basis of this organisation. It should be noted here that a little earlier certain international organisations had appeared, and shamanic leaders were involved in their foundation and operation (e.g. N. Stepanova, who called herself the Supreme Shaman of Buryatia, created the first shamanic organisation in the Republic of Buryatia, and later on organised the Institute of Buryat Shamanism Enherel in Italy (see Romm 2010), while B. Tsyrendorzhiev created a branch of his organisation Tengeri in Berlin). Foreign formations do not affect the activity of the Siberian and, in general, Russian shamanic organisations.

However, in Russia shamans still do not want a comprehensive centralisation, not only because they well remember the Soviet period, with its crosscutting vertical subordination, but because many of them know the traditional canons. This was confirmed as a result of a casus that was provoked by an urban shaman, actively proving himself in the cultural and ethno-tourist fields and working under the pseudonym Elville Olard Dixon. In the spring of 2009, he and his wife (pseudonym Shoncholay Hovenmey) announced on the Internet, and then in the media and on TV, elections of the Supreme Shaman of Rus- 
sia. On a website specifically created for this purpose a long list of candidates for the post was given (by the way, I counted at least six dead people among them). Of course, this was not an adjustment for elections 'in two worlds'; the misunderstanding resulted from a basic ignorance of the situation, since the information about the shamans was taken, among other sources, from someone else's scientific publications. I will not linger on the ethical side and details of this rather comical situation, especially regarding its results, but I would like to emphasise the fact that the rather self-proclaimed election committee was showered with letters from Siberian (neo)shamans who found themselves in the list of candidates for such a high position, and from entire shamanic organisations demanding to remove their names from the electoral list as they did not know at all about this action and had not given their consent to participate in it. The basic requirement, of course, was to stop the action itself. Serious (neo)shamans and leaders of shamanic associations, such as Ai-Churek S. Oiun and B. Rinchinov, spoke out against such a policy for many reasons, including the fact that they did not want to build a vertical structure with a focus on the capital.

Obviously, the politicisation of the shamanic revival in the form of shamanism, embedded in a religious-political framework and structures, did not correspond to the ideas of the Siberian adepts about shamanism. Assuming that neoshamanic practices significantly changed their functioning in comparison with traditional shamanism, (neo)shamans were not ready to create a religious and administrative structure on the country level. On the local level, on the other hand, many of them are not only members of the LROS, thereby forming a grassroots religious unit, but also participate in the political life - for example, in the election campaigns. However, they try not to get involved in various political actions, especially on the side of the protesters. For example, Buryatian youth protests against the inclusion of the Ust-Ordynsky Buryat Autonomous Region and the Aginsky Buryat Autonomous Region in bigger administrative entities were not supported by shamanic organisations, although in words many neoshamans were in agreement with the ideas of the young. At the same time some of the local neoshamans in several regions, having been invited to official ceremonies to support the governmental position, participated in them. They are also engaged in consulting officials on various issues:

Having arrived at the house of the old man Danilo (Sushkenov - V. Kh.), we noticed at the gate two black Volgas with blue licence plates; it turned out that the shaman was consulting the employees of the Department of the Interior Affairs. (Ketkovich 2004)

Sometimes even officials of the 'first circle' become parentalised by them. 
Spiritual and cultural components, naturally, became more important for modern shamanism. National revival, as well as the prevailing cultural context, helped to actualise these sides of traditional shamanhood and shamanism (on the distinction of the terms see Kharitonova 2004, 2006; Funk \& Kharitonova 2012 [1999]) already in the period of perestroika in the country.

\section{SHAMANISM AND CULTURAL REVIVAL}

The national-cultural revival during the perestroika period aspired to find distinctive, special components in the culture of ethnic groups interested in the revival. It was shamanism, which was transformed and almost eradicated during the Soviet period and the remains of which could still be found in Siberia, that met the requirements (about the peculiarities of the transformation of shamanism in the USSR see Kharitonova 2010). However, shamanism itself with its personality cult and specific features that allowed to predict, diagnose, and heal - intensified in line with the development of traditional healing. And in the process of cultural revival priestly practices were put at the forefront, easily updated by the well-preserved domestic shamanhood (on the preservation of traditions see, e.g., Funk 1997; Pimenova 2007). At the same time a folklore component of shamanism came to the fore, creating curious processes. Below I will dwell upon a few important and interesting issues.

The first one is the inclusion of shamanic elements in revived folk festivals (created according to scenarios, written, inter alia, by using ethnographic and folklore literature), some of which have become legitimised in their republics (for example, Ysyakh in the Republic of Sakha since 1991, Chyl-Pazy in Khakassia since 1995, Alhalalalay in the settlement of Kovran since 1987, and officially in the Kamchatka region since 2010 (http:/www.sgan2009.ru/Prasdniki/Alxalalay/ Alxalalay.html)), whereas others exist in more modest local variants.

The second issue is the very frequent occurrence of actors in the role of shamans on the professional stage and in films, and (neo)shamans on the stage and screen as shaman-healers and soothsayers. Unfortunately, sometimes they show a complete ignorance about the traditions and actively violate them.

The third topic of interest is the folklorisation of phenomena along with their desacralisation; for example, in the case of performing shamanic folklore by the shamans' descendants of the Kosterkin clan (see Dobzhanskaya 2013: 75-85). The transfer of the elements of shamanic practice onto the professional scene and, especially, into the sphere of amateur performance, is not a new phenomenon; such attempts existed already in the Soviet period. However, the general context of what is happening is rather interesting: people who consider 
themselves modern shamans or direct descendants of shamans appear on the stage and in the sphere of amateur art. None of them is forced to do it under the pressure of propaganda of atheism; conversely, there is an active and explicit policy of religionisation in the country.

What is it: the legacy of atheistic education of the past or rather the victory of the world religions, particularly Protestantism, actively spreading in the northern and Siberian regions and changing attitudes towards traditions? Perhaps this is the result of living in the country that has chosen the path of atheism for several decades, which allowed the desacralisation in their minds of both the image of a shaman and the phenomenon of shamanism as a whole?

In any case, the main component of shamanism remains the most important for the direct and indirect followers of shamans: its soothsaying (clairvoyant) and healing origin of shamanism, the revival and modernisation of which has been actively built into the healing context since the 1980s.

\section{TRANSFORMATION OF SHAMANISM AND TRADITIONAL HEALING}

A major component of the modern variants of shamanism is the practice of spiritual healing, coupled with soothsaying / fortune-telling, as well as with the elements of folk healing on the one hand and professional psychotherapy on the other. This is predetermined by the orientation of traditional shamanism to restore the spiritual and psycho-physiological integrity of the members of a society, those patronised by a shaman. The revival of shamanism, we can say, is in perfect harmony with the process of the emergence of traditional healing, which began in the 1980s. Let us leave aside the question of the development level of Soviet medicine and the collapse of the health care system in the era of perestroika, which are often used to explain the appearance of traditional healing as a profession and actualisation of shamanic healing practices. Let us direct our attention to other processes, those closer to shamanism.

The revival of interest in the healing component of spiritual culture and the healing practices developed in parallel to the emergence of traditional healing - a phenomenon representing, in the post-Soviet space, an analogue of traditional medicine, which was forming in the later versions in the twentieth century in some regions (or countries) as either publicly (China) or privately (e.g. Korea) defined systems based on ethnic magical-medical practice. The Russian Federation partly follows the way of China: of course, the Russian system of traditional healing was not formed by a directive of the leader of the country (cf. China: Lynteris 2012), but with the active cooperation by a number of in- 
terested individuals from medical science and scientific areas related to it. The process evolved, on the one hand, as a spontaneous revival of ethno-medicine (and magical-medical as well as magical-mystical practices), and, on the other hand, as regulated from above by a scientific community of primarily medical and psychological orientation.

Shamanism, based on psychotherapy and spiritual practices, as well as on healing activity, was also drawn into it. In fact, many neoshamans came to the practice indirectly: they studied with various healers, hypnotists, and parapsychologists; some took special courses at the schools of healers. Naturally, further on neoshamans and traditional healers developed, for the most part, in parallel: some neoshamans as well as practicing healers received diplomas of healers, passed a range of certifications, became members of academies, were issued credentials similar to state certificates, indicating the existence of a scientific degree of a Candidate or Doctor of Science (including in the field of psychology). Even after groups of neoshamans, having been united in a modern way, legally established their centres in the manner of the LROS, they still continued to be engaged in spiritual and practical healing, ${ }^{4}$ except that, as a result of administrative checks of their work, they removed price lists for their services from the walls (see, e.g., Kharitonova 2008). It should be mentioned here that there are usually no indications of healing activity in the rules of the LROS (to practice it, beginning in 1993, one needs to have documents about special education and licenses).

Thus, de jure, healing practice in religious organisations turns out to be illegal. De facto it continues to exist, but is not advertised; however, the local population knows what traditional shamans, healers, and doctors have always done and actively ask neoshamans for help.

Since 2012, the situation with spiritual healing has become much simpler: according to the new Law on Health Care (in fact, effective from 1 January 2012), this activity is unrelated to medicine and does not require licensing. The healing services offered by shamans of various kinds are not tracked and hence are not prohibited (as, in fact, is the entire ethnic medicine). Variants of psycho-correction, offered in conjunction with shamanic techniques, also lie on the conscience of psychologists/shamans; typically, such professionals are certified for some areas of psychology and psychotherapy, but that does not mean that they work within the framework of only those practices for which they are certified.

As the demand for shamanic services is currently considerable not only in traditional shamanic regions, but also among certain parts of the population of the world, even foreign clients turn to specialist of revived shamanism for professional help. They come to Russia as a variant of specific scientific tourism 
or ethno-tourism; experts themselves travel to different countries of the world, where they give their training seminars (see http://www.shamanstvo.ru/news_ shaman/2005/news-37.htm) with shamanic healing sessions, and some of them organise permanent working centres (e.g., as already indicated, N. Stepanova in Italy and France, etc.); clients and shamans-healers meet at scientific conferences, and rather often at events of pseudo-scientific nature.

In fact, healing practices nowadays do not even require certification; however, the desire to get some certificates from representatives of revived shamanism is rather obvious: sometimes not only psychologists / urban shamans, but also neoshamans seek different ways to be engaged in the context of science.

\section{BETWEEN TRADITIONAL RELIGION AND MASS SCIENCE}

Today this situation requires a special detailed analysis (which, unfortunately, cannot be given in a small review article).

For now we can say that at the present time (largely thanks to the Internet) something has formed in the field under discussion that, by analogy with mass culture, should be called mass science. The integration of scientific thought and metaphysical concepts, as well as of the theories based on 'contactee insights' activated as far back as in the 1980s. A magnificent illustration of this were numerous events such as conferences and congresses where, for example, traditional healing was discussed, as well as new psychological areas and even more unusual phenomena explored at that time.

A distinguishing feature of such events is their interdisciplinarity. When representatives of various scientific domains of knowledge assemble, and, moreover, with practising 'discoverers of the truth' through a variety of virtual characters (from traditional spirits, deities, and gods to cosmic teachers and aliens), the basic idea of interdisciplinarity is implemented pretty quickly: those seeking for the truth find themselves between disciplines, as well as between science and 'divine revelation', being convinced that they have managed to integrate both these crafts. In many cases, this makes some people believe that they have gained access to revelations that science is still not able to explain, while someone has already 'felt' it and brings a new truth to the world; others, at the same time, arrive at the conclusion that it is them who help science 'scientifically', and interpret the unknown on another, higher level.

Today mass science, as well as mass culture, is an inevitable and inescapable phenomenon - the Internet and the mass media contribute to it actively. It is impossible to get rid of it, but the situation must be rectified: firstly, for the scientists who identify interdisciplinary methods of research with complex 
research of specific phenomena (of which their personal knowledge is often insufficient to interpret the subject through basic knowledge and methods of other sciences, in which they are not experts), not to mislead colleagues and not to contribute to the transformation of science into mass science, and secondly, for spiritual practices (including traditional) to remain spiritual practices and do their (rather important) business and not to offer scientific theories.

All this is relevant to neoshamanism and experiential shamanism and especially urban shamanism. It is no secret that many modern shamans of various kinds are people with high educational status. However, every particular person has his/her own thoughts about the relationship between science and shamanic practices. In general, we could say that some of them, due to their education and activities, including scientific, went into shamanism, while for others, on the contrary, science was needed when they felt the shaman's call, in order to understand what was happening to them - to clarify the scientific bases of shamanic practices and conditions.

However, unfortunately, some of the current shamans have not refused the possibility of a simple acquisition of certificates of different types: it is about inclusion in the domain of academic degrees and titles through commercial organisations offering diplomas and certificates, including master's and doctor's degrees, in the field of psychology and of different specialisations in the field of medicine, as well as membership in academies. Behind all this lies a serious problem of faking: either intentional (with commercial and other purposes in mind) or unintentional (delusion because of ignorance, self-deception because of the individual features of the psyche, etc.); sometimes both these factors elegantly combine.

Unfortunately, this leads to necessitated scientific fraud. Sometimes there are references to the works of 'well-known shamanologists' who actually do not even have secondary education, in scientific publications, including dissertations. However, some researchers mistake foreign aliases of current publishers for original names and include them in the list of references. On the other hand, people who in fact have just read ethnographic or esoteric literature offer healing services and call themselves shamans initiated by the Great Spirit.

There is certainly also a positive inception in the introduction of the phenomenon of mass science (one might say, in its revival, as well as that of shamanism: it is not the first time for the humanity to step on the same rake). We might hope that the current situation will make serious researchers study, more actively, well-founded psycho-physiological and neuro-psychic subtexts of shamanism and other such phenomena; yet for now, unfortunately, enthusiasts or shamans themselves are engaged in it to a larger extent. However, the latter often prefer other spheres of operation, for example, ethno-tourism. 


\section{TRAVELLING AROUND THE PLACES OF POWER}

'Shamanisms' appeared rather quickly in this sphere (if we understand the term ethno-tourism in its extended version). Initially, the focus was on individual trips of invited (neo)shamans to large Russian cities (especially to Moscow), the neighbouring countries, and to countries further abroad. They travelled to participate in various events (conferences, including scientific and business forums with a 'scientific' component), to organise so-called educational seminars (where they taught the basics of Shamanism) as well as rituals (see, e.g., Oiun 2011). ${ }^{5}$ Naturally, in return, non-resident and foreign fans of olden times flocked to the depth of the country to get acquainted with the local way of life of shamanists and shamans. And if they experienced some disappointment with regard to shamanists - they did not really seem to like the expected 'religionists' and were sometimes even not interested in these olden times - in just 3-5 years tens and hundreds of 'shamans' appeared out of nowhere, satisfying all their queries. This was true especially in terms of teaching them shamanic techniques: in the 1990s the new shamans still tried to make a secret of their knowledge, and in the twenty-first century, suddenly it became clear that there was nothing to hide (quantity destroyed quality) and they began active trainings and initiations right on the premises. Simultaneously, various books containing revelations about the techniques of shamanism started appearing rather actively in mass science (see, e.g., Sarangerel 2003; Fedorov 2005).

In the $2000 \mathrm{~s}$, new variants of ethno-tourism emerged. Some neoshamans got their own sites on the Internet and began to develop their ethnic and cultural activity in their small motherland and in different 'sacred' places in the world. Today various groups from Russian cities and foreign countries travel to Siberia to participate in the rituals (including calendar holidays), for the sake of visiting holy places (places of power) and study shamanic craft. All this takes place in shamans' organisations or other venues where cultural and entertainment events are held. There are so-called ethno villages and art houses where, as also in the LROS, such actions are carried out. Even more actively than before, neoshamans visit various events in the capital, while the range of the organisers of such events has expanded and somewhat altered. At specialised exhibitions, seminars, and ceremonies in the capital and other cities, representatives of Russian and foreign shamanism of various kinds can be found. They share their experience and knowledge, and it does not bother anyone, because the globalisation and universalisation of the 'shamanic knowledge' and mental experience have been observed already for a long time. Against this background ethno-tours to Morocco and Nepal, organised by neoshamans 
to visit 'places of power', and inclusion into the shamanic practice do not look so strange anymore (see, e.g., www.kobezhikova.ru/travel.shtml).

Another interesting line that does not particularly stand out from the general stream of shamanic movements is travelling to the North and Siberia in the homeland and visits to the Americas and other continents in search of doping variants of shamanism with Amanita muscaria (fly agaric), ayahuasca (entheogenic brew made out of Banisteriopsis caapi vine, often in combination with various other plants), peyote, etc. (cf. Dobkin de Rios \& Rumrrill 2008). Back in the 1990s, for example, a secret import of raw materials for the producing of ayahuasca began, particularly in Moscow. Interest in it, as well as in peyote, was caused by the stories of Carlos Castaneda and the book, The Way of the Shaman, by M. Harner, as well as the mention of the use of ayahuasca in various scientific publications. Knowledge of Amanita muscaria and other mushrooms stimulated shamanic tours on the Siberian grounds. However, all this has much more to do with urban shamans, rather than with (neo)shamans.

In places where people showed an interest in teaching practices, in exploring the unknown in faraway places, and in rare raw material used to immerse into special states of consciousness, a specific shamanistic business context was formed.

\section{SHAMAN IN THE CONTEXT OF CONTEMPORARY CAPITALISM}

Obviously, in the modern world based on financial calculations, everything mentioned in relation to the development of shamanic activities could not, and should not have been done gratuitously. If we consider that the processes of the revival of shamanism took place in parallel with the redistribution of capital and the spread of capitalism in the country, it would be strange to expect the revival of traditional practices of shamans and healers in the form of bartering. We can compare, for example, how the practice of Reiki in Japan, in the period of the spread of capitalism in the country, was restored, enriched by the idea of 'money equals energy', i.e. according to energy exchange, one should pay in cash for the energy spent by a healer (see Kharitonova 1997: 24); so the idea about the price for a service which had to be paid became natural. The help offered in shamanistic healing centres, i.e. within the LROS, became fee-based. Another aspect is that the 'clergy' found themselves in a difficult situation: because of their status, they do not have the right to trade their services. Naturally, they had to turn to the practice of donations. 
More natural was the approval of the financial side when seminars, workshops, and even shamanic initiations were organised, because there existed appropriate models adopted in the field of education, actively developed in the country during the same period, in the field of teaching psychology and psychotherapy. The western experiential shamanism, which began to penetrate into the territory of the USSR already in the late 1980s, was another, more familiar model.

Thus, the revival of shamanism was initially put on a commercial footing, which was provoked by the socio-economic status of the new shamans - they had to make a living and acquiring the status of a shaman or a healer provided, albeit sometimes modest, earnings. In the period of instability (which saw many people surviving almost without a salary), many viewed this as a way out of a difficult situation, but at the same time most of them went through serious depression and even psychosomatic diseases, which was perceived by many as a shamanic illness. During this period, the idea of a shamanic illness dramatically transformed (or rather, most of the latter-day shamans did not know what the specifics of this state were, because it was often associated with just troubles and misfortunes that befell them (see, e.g., Pimenova 2007).

Practice in one's own region is not always good enough to provide for a decent livelihood for new shamans, so a large number of them move to big cities or the capital, whence it appears easier to go, even for quite long periods, to work in the West. Thus, some of the well-known contemporary practitioners work either in their native regions, or in the capital and other major cities in Russia, or outside the country. Usually fixed, periodically working centres are established: for example, an Altai neoshaman can practice at home, from time to time travel to Salekhard and Moscow, and sometimes also work in Turkey, etc. For some experts Moscow has become their second hometown, where they continuously live, sometimes paying brief visits to their homeland for 'energy supply'. The practice of leaving the place of permanent residence for short-term visits to European countries or Turkey still persists. But attempts are also made to establish regular contacts, with the creation of branches of the LROS in European countries (in Germany, for example), and permanent centres in Italy and France, which was already mentioned above. 


\section{INSTEAD OF CONCLUSION}

Obviously, the revived shamanism is forced to adapt to modern conditions, and transforms according to Soviet and post-Soviet mentality of the authors of its revival and its modern adepts. It would be logical to assume that the process of modernisation is not going to stop. At this stage, in addition to the development of the individual practices in various forms (including the option of combining neoshamanic activities with work in network structures), attempts are being made to consolidate shamanic organisations. However, this has not been accomplished by today, and the established organisations have been disbanded or reformed. In Buryatia in April 2013, the second conference of consolidating shamans, initiated by LROS Tengeri, was held and the same organisation began to build a shamanic temple in Ulan-Ude in September 2013 and re-registered it as the Inter-Regional Centre of Shamans Khaan Tengeri. ${ }^{6}$ However, the ambition of individual leaders to form in Russia a shamanic confession under the current polyvariety of 'shamanisms' is unlikely to succeed, unless they are urged by some new legislative initiatives and social transformations. ${ }^{7}$

\section{NOTES}

1 Some modern scholars sometimes use this term to refer to the practices of neoshamans and (neo)shamans who settle in towns and villages (see, e.g., Shaglanova 2007). I do not see the point in it, as the mentioned transformations (the organisation called Local Religious Organisation of Shamans (LROSH), etc.) are not related to changing rural environment into urban, but to the administration of religious and cultural processes; (neo)shamans-individualists still have their practice in cities, towns, and rural settlements, while the inhabitants in the countryside are regularly involved in the work of urban and community LROSH sections. The organisation is represented in all the republics that legally recognise shamanism as one of the traditional religions.

2 The LROSH Tengeri is currently building a large temple on the territory designated by the organisation; moreover (according to the personal message of the head of the organisation, B. Tsyrendorzhiev), the shamans of this organisation have revived the basics of religious doctrines and the main precepts of shamanism. Interestingly, the shamans attempt to correct traditional ideas about the practice of shamanism, in particular, B. Tsyrendorzhiev has said in one of his interviews: "Today, many ethnographers are wondering how shamans can build their temples, but I think it happened earlier as well, but has been forgotten by now. In the time of Genghis Khan shamanistic temples existed; this can be concluded on the basis of The Secret History of the Mongols. So, the shaman of Genghis Khan, Tengeri, had his house-temple, where he performed rituals, worshipping the eternal blue sky. Because of globalisation, we are departing from traditions, while in other countries people still remember their religious culture. There are shamanistic temples in South Korea, and Shinto temples in Japan, while there are only projects in Mongolia and Russia, but still no temple. And I think now it is the time to build a shamanic temple" (Tsydenova 2013). 
3 Attempts of such consolidation occur in different republics: in Tuva, for example, several organisations are subordinated to M. Kenin-Lopsan and constitute a kind of centralised system; a slightly different variant can be found in the Irkutsk region - the Council of Shamanic Communities of the Baikal Region (see http://www.bur-culture. ru/index.php?id=55).

4 Information about this is not always accurate, and is sometimes unreal, and has appeared in various publications, even before it hit the papers of the Government Commission of the Republic of Tyva (see Kharitonova 2008). For example: "In the waiting room, on the secretarial desk, there was a price list, in which services and their prices were listed in the Tuvan language. Thus, purging a house cost 100 thousand roubles, and with a visit to the kozhuun (administrative district) - 150 thousand roubles (July 1997). The list of services also included the treatment of various diseases and the traditional Tuvan fortunetelling huvaanak. The visitor explains the essence of the problem to the secretary, pays the cashier, takes the receipt and goes to a shaman or a soothsayer. The shaman receives a certain percentage of the fee, the rest goes to the fund of the society" (Myshliavtsev 2009).

5 "In 2004, after a visit to Tuva, Siegfried, the leader of the shamans in Germany, invited me, shamaness of the society Spirit of the Bear, to Bielefeld, Germany, for experience exchange. There I held my first seminar on Tuvan shamanism" (Oiun 2011).

6 The head of a new centralised organisation, B. Tsyrendorzhiev, has big plans, which he willingly shares with reporters: "Currently we are establishing the Institute of Shamanism. In the spring of this year a large conference on the current state of shamanism was held. Shamans and the scientists of the Irkutsk region from the Trans-Baikal Territory attended it. We then adopted a resolution on the unification of shamans. And now we are applying for the establishment of inter-regional centralised religious organisation of shamans, Khaan Tengeri. The organisation will unite not only the shamans living in ethnic Buryatia, but also the ones from other regions of Russia. The shamans of the Omsk region, the Moscow region, and the city of Astrakhan have already applied for membership in this organisation. We are also creating a structure for managing the organisation. So, in that way the supreme shaman will be elected, as well as an assembly called duherig (circle in Buryat). This assembly would include the heads of regional organisations of shamans" (Tsydenova 2013).

7 For example, changes in the Law on Health Care: in the last law of 2012 (Art. 50, Traditional Medicine) shamanic healing is not regulated. However, at present (2015), bylaws are being prepared, according to which the healing practices of not only shamans, but also of other specialists will be largely restricted. 


\section{REFERENCES}

Dobkin de Rios, Marlene \& Rumrrill, Roger 2008. A Hallucinogenic Tea, Laced with Controversy: Ayahuasca in the Amazon and the United States. Westport: Praeger Publishers.

Dobzhanskaia, Oksana 2013. Nganasanskie obriadovye pesni v ispolnenii naslednikov shamana Demnime: K probleme imitatsii shamanskogo rituala. [Nganasans' Ritual Songs Performed by the Successors of the Shaman Demnime: On the Problem of Ritual Imitation.] In: V. Kharitonova (ed.) Epicheskoe nasledie i dukhounye praktiki $v$ proshlom $i$ nastoiashchem. Etnologicheskie issledovaniia po shamanstvu i inym traditsionnym verovaniiam i praktikam. T. 15, ch. 1. Moskva: IEA RAN, pp. 75-85.

Estrin, Anatolii 2006. 100 shamanskikh zagovorov: Praktika Vizardiki. [100 Shamanistic Spells: Practice of Vizardika.] Sankt Peterburg: Krylov.

Fedorov, Vladimir 2005. Tainy vudu i shamanizma: Vo vlasti potustoronnikh sil. [Secrets of Voodoo and Shamanism: In the Power of Supernatural Forces.] Moskva: Veche.

Funk, Dmitrii 1997. Teleutskoe shamanstvo: traditsionnye etnograficheskie interpretatsii i novye issledovatel'skie vozmozhnosti. [Teleut Shamanhood: Traditional Ethnographic Interpretations and New Research Opportunities.] Moskva: IEA RAN.

Funk, Dmitrii \& Kharitonova, Valentina 2012 [1999]. Shamanstvo ili shamanism? [Shamanhood or Shamanism?] In: "Izbranniki dukhov"- "Izbravshie dukhov": Traditsionnoe shamanstvo i neoshamanizm. Pamiati V.N. Basilova (1937-1998). ["Chosen by Spirits" - "Chosen Spirits": Traditional Shamanhood and Neoshamanism. In Memory of V.N. Basilov (1937-1998).] Etnologicheskie issledovaniia po shamanstvu i inym traditsionnym verovaniiam i praktikam, T.17. Moskva: IEA RAN, pp. 109-137. Available at http://static.iea.ras.ru/books/Kharitonova_17_Tom.pdf, last accessed on October 21, 2015.

Ketkovich, Vlad 2004. Sovremennyi buriatskii shamanism. [Modern Buryat Shamanism.] Geografiia, No. 28. Available at http:/geo.1september.ru/view_article.php?id=200402809, last accessed on October 21, 2015.

Kharitonova, Valentina 1997. Tselitel'stvo i metodika Reiki. [Healing and Reiki Technique.] VITA: Traditsii. Meditsina. Zdorov'e, No. 2, pp. 23-25.

Kharitonova, Valentina 2004. Shamany i shamanisty: nekotorye teoreticheskie aspekty izucheniia shamanizma i inykh traditsionnykh verovanii i praktik. [Shamans and Shamanists: Some Theoretical Aspects of the Study of Shamanism and Other Traditional Beliefs and Practices.] Etnograficheskoe obozrenie, No. 2, pp. 99-118. Available at http://journal.iea.ras.ru/archive/2000s/2004/2.htm, last accessed on October 21, 2015.

Kharitonova, Valentina. 2006. Feniks iz pepla? Sibirskii shamanizm na rubezhe tysiacheletii. [Phoenix from the Ashes? Siberian Shamanism at the Turn of Millennium.] Moskva: Nauka. Available at http://static.iea.ras.ru/books/Phoenix.pdf, last accessed on October 21, 2015.

Kharitonova, Valentina 2008. Sovremennaia religioznaia situatsiia v Respublike Tyva. [Modern Religious Situation in the Republic of Tyva.] In: D. Funk (ed.) Tiurkskie narody Vostochnoi Sibiri. [Turkic Peoples of Eastern Siberia.] Moskva: Nauka, pp. 166-184. 
Kharitonova, Valentina 2010. Politika, korrektiruiushchaia traditsii: (neo)shamany i (neo)shamanizm v SSSR i RF (1922-2010 gg.). [Politics Correcting Traditions: (Neo)shamans and (Neo)shamanism in the USSR and the Russian Federation (1922-2010).] In: František Bahenský a kolektiv. Národnostní politika na teritoriu bývaleho SSSR. Praha: Etnologický ústav Akademie věd České Republiky, pp. 85-120.

Kharitonova, Valentina \& Ukraintseva, Iuliia 2007. Zov bezmolviia, ili pochemu oni shamany? [Call of Silence, or Why Are They Shamans?] Races and Nations, Vol. 33. Moskva: Nauka, pp. 218-245.

Kharitonova, Valentina \& Ukraintseva, Yulia 2012. Destined for Shamanic Inspiration: An Integrative Study of Buryat (Neo)Shamans. In: D. Eigner (ed.) Consciousness: Cultural and Therapeutic Perspectives. Frankfurt am Main \& Berlin \& Bern \& Bruxelles \& New York \& Oxford \& Wien: Peter Lang International Academic Publishers, pp. 109-130.

Lynteris, Christos 2012. The Spirit of Selflessness in Maoist China: Socialist Medicine and the New Man. Basingstoke \& New York: Palgrave Pivot.

Myshliavtsev, Boris 2009. Normativnaia kul'tura tuvintsev (konets 20 - nachalo 21 veka). [Regulatory Tuvan Culture (Late 20th - Early 21st Century).] Available at http:// samlib.ru/m/myshljawcew_boris_aleksandrowich/tuva-1.shtml, last accessed on October 21, 2015.

Oiun, Liudmila 2011. Podruzhilsia s tuvinskimi shamanami. [Becoming Friends with Tuvan Shamans.] Tuvinskaya pravda. Obschestvenno-politicheskaya gazeta, No. 64, June 23. Available at http://www.tuva.asia/news/tuva/3566-shamany. html, last accessed on November 4, 2015.

Pimenova, Kseniia 2007. Vozrozhdenie i transformatsii traditsionnykh verovanii i praktik tuvintsev $v$ postsovetskii period: osnovnye problemy. [The Revival and Transformation of Traditional Beliefs and Practices of Tuvinians in Post-Soviet Tuva: Main Problems.] Dissertation for the degree of Candidate of Historical Sciences. Moskva: IEA RAN. Available at http://dlib.rsl.ru/viewer/01003052651\#?page=1, last accessed on November 10, 2015.

Romm, Valerii 2010. Interv'iu s Verkhovnoi shamankoi Buriatii Stepanovoi Nadezhdoi Anan'eunoi. [Interview with the Supreme Shaman of Buryatia, Nadezhda Stepanova.] Available at http://slavzso.narod.ru/s-d/10/S3.html, last accessed on October 21, 2015.

Sarangerel 2003. Zov shamana: Dreunie traditsii i dukhounye praktiki. [Call of the Shaman: Ancient Traditions and Spiritual Practices.] Moskva: Fair-press.

Shaglanova, Olga 2007. Shamanizm u buriat Tunkinskoi doliny (Vtoraia polovina XIX$X X v v$.). [Buryat Shamanism in Tunka Valley (second half of the 19th and the 20th cc.).] Dissertation for the degree of Candidate of Historical Sciences. Ulan-Ude. Available at http://dlib.rsl.ru/01002618387, last accessed on November 10, 2015.

Townsend, Joan B. 2004. Core Shamanism and Neo-Shamanism. Shamanism. In: Marico Namba Walter \& Eva Jane Neumann Fridman (eds.) Shamanism: An Encyclopedia of World Beliefs, Practices, and Culture, Volume 1. Santa Barbara, California \& Denver, Colorado \& Oxford, England: ABC-CLIO, pp. 49-56. 
Tsydenova, Ariuna 2013. Shamanskii khram v Buriatii. [Shaman Temple in Buryatia. Interview with B. Tsyrendorzhiev.] Baikal 24: Informatsionnyi portal. September 17. Available at http://www.baikal24.ru/page.php?action=showItem \&type $=$ article\&id=14136, last accessed on October 21, 2015.

Winkelman, Michael 2004. Neuropsychology of Shamanism. In: Marico Namba Walter \& Eva Jane Neumann Fridman (eds.) Shamanism: An Encyclopedia of World Beliefs, Practices, and Culture, Volume 1. Santa Barbara, California \& Denver, Colorado \& Oxford, England: ABC-CLIO, pp. 187-196. 